\title{
MIND MAP DALAM PENGAJARAN KETERAMPILAN MENULIS DAN MEMBACA
}

\author{
oleh Iman Santoso \\ FBS Universitas Negeri Yogyakarta
}

\begin{abstract}
A mind map is a graphic form showing how related ideas are organized. Useful as a graphic organizer of ideas, it is a concept map made on the basis of the principles of how the brain works, that is, through association and imagination, simultaneously maximizing the function of the right and left hemispheres of the brain. Its essence is that the main idea is placed in the middle and then, regarded as its center, it is then connected with lines to supporting ideas having certain associations with it.

A mind map can be used to help develop skills in writing and reading texts written in such a language as German. In developing learners' writing skills, it is to be employed before they write a composition, functioning in this case as a tool for organizing ideas and seeing relations between them and also as guidance in writing a composition. In developing reading skills, it can be employed in the pre-reading phase as an advance organizer enabling readers to have a general idea of the contents of the text. It can also be employed after the reading activity to help give readers training in organizing the information in the text.
\end{abstract}

Keywords: mind map, writing and reading skills

\section{A. Pendahuluan}

Dalam pengajaran bahasa Asing dikembangkan keterampilan berbahasayang bersifat produktif, yaitu berbicara dan menulis; serta keterampilan berbahasa yang bersifat reseptif berupa membaca dan mendengar. Tugas pengajar bahasa Jerman sebagai salah satu bahasa Asing yang diajarkan di SMA dan PT adalah membimbing anak didiknya untuk bisa menguasai keempat keterampilan berbahasa tersebut dengan baik yang didukung penguasaan kosakata dan struktur gramatikal bahasa Jerman yang baik pula. Tujuan tersebut tidaklah selalu mudah untuk 
diraih, karena proses belajar mengajar bahasa Jerman sebagai sebuah sistem terdiri atas berbagai aspek yang saling mempengaruhi.

Pengajar sebagai pemegang otoritas yang menjamin keberlangsungan proses belajar mengajar di kelas mempunyai tugas untuk memilih pendekatan yang tepat- baik secara filosofis dan operasional - agar materi pelajaran yang disampaikannya bisa dipahami oleh siswanya. Pada sisi lain proses transfer ilmu tersebut juga tergantung pada kemampuan siswa untuk mengolah dan menyimpan informasi yang diperoleh ke dalam memorinya. Lebih jauh bagaimana cara siswa mengolah informasi yang diperoleh juga sangat tergantung pada berbagai faktor psikologis, salah satu diantaranya adalah faktor intelegensi.

Dengan mengacu pada penemuan Gardner (Supamo, 2004:1920) terdapat sembilan jenis intelegensi yaitu intelegensi linguistik, matematis-logis, visual-spatial, kinestetik-badani, musikal, interpersonal, intrapersonal, lingkungan dan eksistensial. Jenis intelegensia tersebut mempengaruhi cara belajar siswa, sebagai contoh siswa yang memiliki kecerdasan musikal akan dapat belajar dengan baik apabila diiringi musik atau belajar melalui menyanyi. Adanya beragam jenis kecerdasan tersebut membawa implikasi bagi pengajar untuk tidak hanya menggunakan satu model pembelajaran yang sesuai dengan satu jenis kecerdasan saja. Pengajar misalnya dapat menggunakan selingan musik saat mengajar agar siswa yang memiliki intelegensi musikal dapat termotivasi untuk belajar, atau menggunakan gambar, grafik dan media visual lainnya sehingga siswa yang memiliki kecerdasan visual-spatial juga terfasilitasi.

Salah satu cara yang dapat digunakan pengajar untuk membantu pembelajar agar dapat mengolah informasi dengan baik adalah menggunakan media dan teknik pengajaran yang bersifat visual, seperti menggunakan video, gambar, peta, grafik ataupun peta konsep. Peta konsep yang juga sering disebut sebagai graphic organizer oleh Bromley (via Dalrymple, 2003:7) digambarkan sebagai "a visual representation of knowledge that promote active learning through arranging important textual information into a pattern or structure. Dengan kata lain graphic organizer merupakan representasi visual pengetahuan yang membantu 
proses belajar dengan cara mengorganisir informasi-informasi penting ke dalam pola atau struktur tertentu. Penggunaan grafik semacam ini telah diteliti oleh Lee (2004:1) dan penemuannya menunjukkan bahwa grafik sebagai gambaran sebuah konsep dapat meningkatkan kemampuan menulis responden terutama pada aspek koherensi

Salah satu bentuk pemetaan informasi secara grafts yang telah dikenal oleh pengajar bahasa Jerman adalah Asosiogram (Wortigel). Asosiogram biasanya digunakan diawal pelajaran sebagai pengantar untuk masuk ke dalam inti pelajaran, yang dilakukan dengan cara mengumpulkan ide-ide siswa yang terkait pada satu ide pokok. Malia (2003) dalam penelitian tindakan kelasnya menemukan bahwa penggunaan asosiogram dalam perkuliahan menulis dapat meningkatkan hasil belajar mahasiswa dan mahasiswa terlihat lebih bergairah dan termotivasi saat mengikuti perkuliahan menulis.

Bentuk peta konsep lain adalah Mind Map yang ditemukan oleh Tony Buzan sekitar tahun 1974 lalu. Mind Map menurut Heuer (2001:2) dapat memvisualisasikan jalan pikiran, serta menunjukan bagaimana ideide saling terkait satu dengan yang lainnya dan membantu menyajikan informasi secara cepat, serta untuk memahaminya.

Oleh penemunya, Mind Map terutama ditujukan untuk mengatasi keterbatasan memori yang dimiliki manusia. Pada perkembangannya Mind Map digunakan dalam berbagai bidang terutama untuk memetakan pemikiran atau konsep sehingga mudah dipahami, diingat serta dipanggil kembali. Dan menurut Heuer (200:3 - 4), Mind Map dapat diterapkan dalam pengajaran bahasa Jerman untuk membantu pengembangan keterampilan produktif dan reseptif. Terkait dengan hal itu, dalam tulisan ini akan dipaparkan apa itu Mind Map, cara penyusunan dan penerapannya dalam pengajaran bahasa Jerman, terutama untuk mengembangkan keterampilan menulis dan membaca.

\section{B. Pengertian Mind Map}

Secara etimologis kata Mind Map berasal dart bahasa Inggris Mind yang berarti pikiran dan Map yang berarti peta, dengan demikian 
Mind Map dapat diartikan sebagai peta pikiran. Berdasarkan makna tersebut, maka Mind Map dapat digambarkan sebagai sebuah cara untuk menggambarkan atau memetakan secara visual pemikiran seseorang.

Mind Map pertama kali dikembangkan oleh Buzan berdasarkan atas kenyataan bahwa kemampuan manusia untuk menyimpan dan mengolah informasi dalam memorinya sangatlah terbatas. Di sisi lain, berdasarkan temuan di bidang neurologi terlihat bahwa otak manusia secara fungsional dapat dibagi atas dua bagian yang masing-masing mempunyai fungsi berbeda. Belahan otak sebelah kanan berperan pada pemikiran yang bersifat imajinatif, kreatif, ruang (Spatial), holistik dan non-linear. Sedang belahan otak sebelah kiri sangat berperan pada pemikiran yang bersifat logis, matematis dan linier. Sebuah informasi akan mudah untuk disimpan, diingat dan dipanggil kembali bila informasi tersebut dikelola dengan memaksimalkan fungsi dua belahan otak tersebut. Selain itu menurut Buzan (2004:18). otak berfungsi secara alamiah dengan dua kunci yaitu imajinasi dan asosiasi, dan cara kerja Mind Map menyesuaikan cara kerja otak itu. Mind Map digambarkan oleh Buzan (2004:7) sebagai berikut:

Struktur alamiah Mind Map berupa radial yang memancar keluar dart gambar sentral. Mind Map menggunakan garis, lambang, kata-kata, serta gambar, berdasarkan seperangkat aturan yang sederhana, mendasar, alami, dan akrab bagi otak

Oleh karena itu, dalam situs www.mind-map.com ditegaskan lebih lanjut oleh Buzan bahwa A Mind Map is a powerful graphic technique which provides a universal key to unlock the potential of the brain. Sebagai sebuah peta, Mind Map tak ubahnya sebuah peta kota. Pusat kota merupakan titik pusat yang mewakili ide / gagasan pokok kemudian terhubungkan oleh jalan-jalan utama yang merepresentasikan pikiranpikiran pendukung pada tingkat pertama, dan akan terus bercabang menjadi jalan-jalan yang lebih kecil mengikuti wawasan pemikiran. Sifat imajinatif dari Mind Map diperlihatkan dari warna dan gambar yang tertera, sedang asosiasi antar bagian ditunjukan oleh garis-garis yang menghubungkannnya. Hubungan tersebut tentu saja harus bermakna. 
Pada awalnya, Mind Map digunakan untuk mengatasi kelemahan dari proses pencatatan yang biasanya dilakukan dengan cara linier menggunakan kata-kata, angka, logika dan urutan. (Buzan, 2004:60 ). Cara seperti ini memiliki hambatan, karena informasi akan sukar untuk disimpan di otak ataupun dipanggil kembali saat diperlukan, terutama dikarenakan sifatnya yang monoton. Sebaliknya Mind Map memberikan gambaran secara global sebuah gagasan yang mengkaitkan satu informasi satu dengan yang lain lewat sebuah asosiasi dan diperkuat secara imajinatif dengan bantuan gambar dan warna. Di samping itu Mind Map akan membantu kita dalam mengkaitkan informasi baru dengan informasi yang telah ada di otak.

Mind Map mempunyai fungsi yang sangat bermanfaat dan sangat beragam, antara lain Mind Map membantu kita menjadi lebih kreatif, memecahkan masalah, belajar lebih cepat dan efisien, melihat gambaran secara keseluruhan, membuat rencana, membantu dalam berkomunikasi (Buzan, 2004:10). Dan manfaat yang sedemikian banyak itu, tidak heran jika Mind Map digunakan dalam berbagai bidang seperti dalam bidang pemasaran, perencanaan, presentasi, negosiasi, membuat ringkasan sebuah buku, membuat catatan kuliah, hingga merencanakan kegiatan di hari libur.

\section{Penyusunan Mind Map}

Mind Map menurutAprea (2003:4 6) dapat disusun dengan langkah-langkah sebagai berikut:

1). Sebuah Mind Map selalu dimulai dari ide pokok yang digambarkan atau ditulis di bagian tengah sebuah kertas putih yang diletakan mendatar. Ide pokok ini merupakan pusat dari Mind Map dan bisa diibaratkan sebagai pusat kota atau batang sebuah pohon.

2). Dan ide pokok tersebut dibuat garis-garis penghubung yang melambangkan sebuah asosiasi dengan bagian-bagian pendukung dari ide pokok tersebut. Garis penghubung ini bisa diibaratkan sebagai cabang utama dari batang pohon. Nama cabang yang melambangkan ide pendukung dari ide pokok tersebut hendaknya ditulis dengan huruf cetak. 
3). Cabang-cabang utama tersebut dapat diperinci lagi menjadi ranting pertama, kedua dan seterusnya yang merupakan ide-ide pendukung dari ide yang ada di cabang utama.

4). Setiap pemikiran baru dapat ditambahkan disini, namun harus dilihat apakah pemikiran tersebut langsung berhubungan dengan pusat (ide pokok) atau dengan cabang pada level 1 , atau mungkin merupakan bagian dari ranting yang melambangkan tahapan pemikiran pada level 2. Dengan demikian semua ide yang muncul selalu memiliki asosiasi tertentu dengan ide besarnya yang bersifat lebih umum. Untuk memudahkan dalam pembacaannya, ide-ide tersebut hendaknya dituangkan dalam kata kunci, garis penghubung diberi warna yang berbeda-beda dan dilengkapi dengan ikon-ikon atau gambar tertentu.

5). Langkah terakhir adalah melihat apakah pola pemikiran kita sudah tergambar dengan baik. Jika perlu Mind Map tersebut dapat dirubah strukturnya, atau dilengkapi dengan asosiasi barn. Selanjutnya juag dapat dilihat apakah antar cabang utama ada hubungan pintas yang perlu ditandai dengan bentuk garis tertentu

Sebuah contoh Mind Map ada dalam situs www.mind-map. com yang menggambarkan riwayat hidup Lars-Eric Edvinson. Gagasan utamanya adalah riwayat hidup yang kemudian bercabang menjadi lima cabang utama berupa Edvinson, latar belakang (Hintergrund), hobi (Hobbies), pekerjaan (Arbeit), dan keluarga (Familie). Dari lima cabang utama tadi kemudian bercabang lagi pada pemikiran-pemikiran ditingkat ke dua yang masih terkait erat dengan pemikiran/ide pada cabang-cabang utama, demikian seterusnya. Sebagai contoh, pada cabang utama hobi dibagi lagi menjadi cabang yang lebih kecil terdiri astronomi, olah raga, permainan dan ornitologi, demikian seterusnya. Dari Mind Map tersebut dapat dilihat bahwa Mind Map merupakan gambaran menyeluruh dari proses berpikir yang dilengkapi dengan jalan pikiran beserta elemenelemennya. 


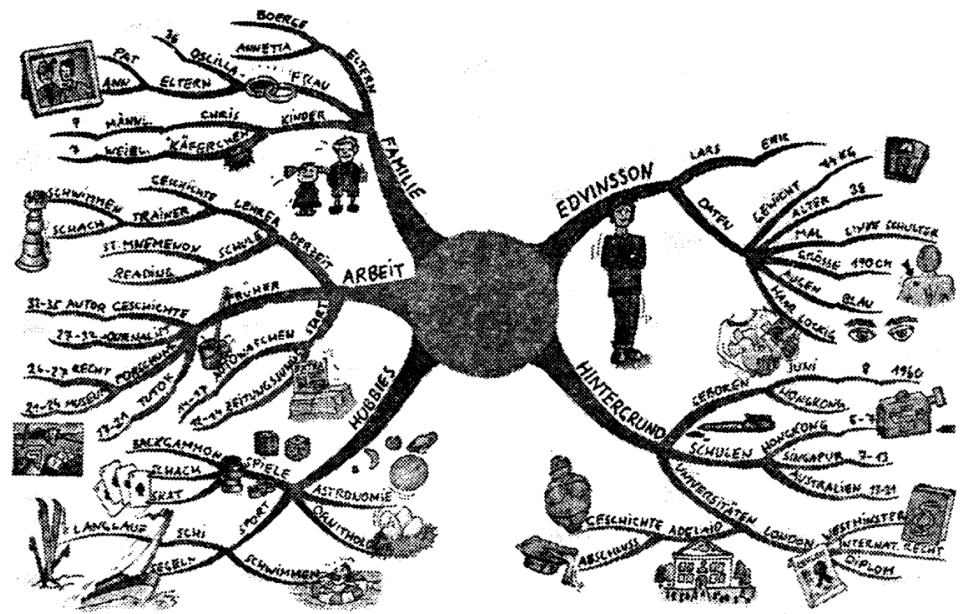

Gambar 1. Mind Map tentang Data Pribadi Lars-eric Edvinsson

\section{Penerapan Mind Map dalam Pengajaran Bahasa Jerman}

Pada sub-Bab sebelumnya telah dijelaskan bahwa Mind Map dapat diterapkan pada banyak bidang termasuk adalah dalam bidang pengajaran. Aprea (2003:7) menyebutkan bahwa teknik pemetaan seperti Mind Map dapat digunakan sebagai strategi mengajar (Lehrstrategien) dan bagi pembelajar bisa dimanfaatkan sebagai strategi belajar dan berpikir (Lern-und Denkstrategien).

Sebagai strategi mengajar Mind Map merupakan cara untuk mempresentasikan pengetahuan pada pembelajar, terutama agar sebuah pengetahuan yang kompleks dapat digambarkan secara lebih terstruktur sehingga mudah dipahami. Selain itu Mind Map juga dapat digunakan pada awal perkuliahan untuk memberikan gambaran sekilas mengenai isi perkuliahan, sehingga mahasiswa memiliki gambaran yang utuh mengenai materi kuliah yang akan dipelajarinya. Sebagai strategi belajar dan berpikir, Mind Map merupakan hasil kreativitas dari pembelajar yang bisa digunakan untuk berbagai hal, antara lain: (1) mengaktifkan pengetahuan yang telah dimiliki, (2) mengolah pengetahuan yang diperoleh secara lebih sistematis dan terstruktur dan (3) sebagai cara 
untuk mengulang materi pelajaran secara lebih sistematis dibandingkan dengan catatan biasa.

Aprea (2003:10) menambahkan bahwa Mind Map memberikan beberapa keuntungan, antara lain: (1) ide pokok dapat dengan cepat dikenali melalui penyusunan yang terpusat, (2) relasi makna antar ide juga dapat dengan mudah diketahui, (3) Kebermaknaan dari suatu ide dapat dilihat dari seberapa jauh letaknya dari pusat. Ide-ide penting terletak tidak jauh dari pusat, sebaliknya ide yang kurang penting akan ada di tepi, (4) Proses mengingat kembali dan pengulangan akan lebih efektif, (5) Informasi atau ide baru dapat dengan mudah ditempatkan dalam kerangka Mind Map.

Dalam pengajaran Bahasa Jerman, Mind Map lebih cenderung dipakai sebagai strategi mengajar berupa alat bantu untuk meningkatkan keterampilan berbahasa pada pembelajar dengan bantuan pengajar. Meskipun demikian Mind Map juga dapat dimanfaatkan oleh pembelajar sebagai strategi belajar jika mereka sudah memahami cara penyusunannya dan telah merasakan manfaatnya. Bimbingan dari pengajar sangat diperlukan bagi pembelajar yang ingin menerapkan Mind Map, karena pars pelajar di Indonesia selama ini lebih banyak dilatih untuk berpikir secara linear. Di samping itu apa yang tertera dalam Mind Map adalah hal-hal pokoknya saja, sehingga pembelajar juga harus dibimbing untuk berpikir secara holistik dan sekaligus dilatih untuk menemukan asosiasi bermakna antar bagian.

Berikut ini akan diberi penjelasan penerapan Mind Map dalam pengajaran bahasa Jerman.

\section{Mind Map dan Pengembangan Keterampilan Menulis dalam Bahasa Jerman}

Keterampilan berbicara dan menulis tergolong pada keterampilan berbahasa yang sifatnya produktif. Keduanya merupakan bentuk aktivitas untuk menyampaikan informasi dari penulis atau pembicara kepada pembaca atau pendengar. Salah satu aspek penting yang harus diperhatikan oleh pembicara/penulis adalah kemampuan untuk menyusun ide-ide dalam sebuah rangkaian yang runtut sehingga mudah dipahami. 
Seorang penulis harus memperhatikan susunan kalimat serta rangkaian ide-idenya agar memiliki koherensi yang baik. Tujuannya adalah agar pembaca dapat dengan mudah memahaminya. Penulis memiliki waktu yang cukup untuk menyusun kalimat dan merevisinya, namun ia tidak akan memperoleh umpan balik dengan cepat dari pembaca apakah tulisannya bisa dipahami atau tidak. Oleh karena itu bagaimana rangkaian ide-ide itu dituangkan dalam sebuah tulisan menjadi sangat penting. Di lapangan sering dijumpai, bahwa kesulitan terbesar yang dialami oleh mahasiswa justru pada bagaimana merangkaikan ide-ide ke dalam sebuah tulisan / karangan dalam bahasa Jerman. Di samping memang mereka terkadang memiliki perbendaharaan kata dan pengetahuan struktur gramatikal yang tidak memadai.

Hal seperti ini juga dialami oleh pembelajar bahasa Inggris. Menurut Lee (2004:1) low english profieciency students have difficulty making their writing coherent. They tend to be more concerned with language matters rather than making meaning. Terkait dengan problem penyusunan sebuah karangan, Mind Map dapat digunakan sebagai langkah awal untuk melakukan pemetaan ide-ide, mulai dari ide utama hingga ide-ide pendukungnya. Dengan kata lain Mind Map merupakan alat bantu untuk mengorganisir ide-ide sehingga sebuah karangan akan memiliki koherensi yang baik. Hal itu juga ditegaskan oleh Jung (2003:121) bahwa salah satu aspek yang perlu dilatihkan dalam keterampilan menulis adalah mengorganisir teks (Gliederung des Textes), dan hal itu bisa dilakukan dengan Mind Map.

Tahapan dalam menerapkan Mind Map untuk mengembangkan keterampilan menulis dalam bahasa Jerman adalah sebagai berikut: (1) Pengajar bersama mahasiswa menentukan tema yang akan ditulis dalam karangan. Atau pengajar mengumpulkan beberapa tema, kemudian meminta mahasiswa untuk memilih tema yang dianggap paling menarik. (2) Tema yang telah dipilih tersebut, kemudian diletakkan ditengah kertas atau papan tulis dan dianggap sebagai ide / gagasan sentral. Gagasan sentral ini dapat dilengkapi dengan gambar agar terlihat lebih menarik dan imajinatif serta membantu kita untuk memusatkan pikiran. (3)

DIKSI Vol.12, No.2, Juli 2005 
Kemudian pengajar meminta mahasiswa untuk mengumpulkan ide-ide utama yang merupakan ide pendukung terhadap gagasan sentral tadi. Untuk mempermudah dapat ditentukan empat atau lima ide pendukung yang akan dihubungkan dengan gagasan sentral, sehingga terbentuk empat atau lima cabang utama. Pada tahap ini pengajar hendaknya membimbing mahasiswa untuk menentukan apakah sebuah ide terkait langsung dengan gagasan sentral sehingga dapat dimasukan pada cabang utama, atau mungkin masuk pada anak cabang di level berikutnya. Dengan demikian akan tersusun secara hirarkis mulai dari gagasan sentral yang sifatnya umum hingga gagasan yang sangat spesifik pada ranting terluar. Proses ini merupakan tahapan untuk menyusun asosiasi antara ide satu dengan ide lainnya, dan untuk memperkuat asosiasi tersebut antar gagasan atau ide dihubungkan dengan garis-garis. (4) Gagasan-gagasan tersebut hendaknya dinyatakan dalam satu kata kunci per baris. Kata kunci tunggal ini akan mempermudah pencetusan ide baru. Selanjutnya untuk memperkuat efek imajinatif, Mind Map tersebut dapat dilengkapi dengan gambar pada setiap cabangnya. (5) Dari setiap cabang utama, mahasiswa diminta untuk menemukan lagi ide pendukung gagasan utama, sehingga dari sebuah cabang utama dapat dibuat beberapa anak cabang. (6) Apabila Mind Map telah tersusun, mahasiswa diminta untuk memulai menuliskan karangannya dengan menggunakan Mind Map tersebut sebagai panduannya. Dengan cara demikian diharapkan pembelajar dapat menulis karangan yang memiliki kesatuan makna yang baik serta runtut.

Contoh, ketika mahasiswa diminta menuliskan karangan mengenai rencana liburan mereka, pengajar dapat memberikan ide pokok berupa "Ferienplan". Selanjutnya sebagai langkah berikutnya pengajar menekankan bahwa cabang-cabang utama dapat diberi label dengan kata tanya Wann? Wo? Was?. Kata tanya Wann? merupakan panduan untuk mengumpulkan ide kapan liburan akan dilaksanakan, kemudian Wo? merupakan kumpulan ide mengenai tempat di mana liburan akan dilakukan, sedang Was? merupakan pemicu untuk mengumpulkan ide apa akan yang dikerjakan saat liburan. Selain itu dapat juga ditambahkan 
satu cabang utama lagi yang diberi label Wer? yang merupakan pemandu untuk mengumpulkan ide mengenai siapa saja yang akan diajak dalam liburan kali ini. Masing-masing cabang utama ini kelak dapat disusun menjadi paragraf dalam karangan yang ditulis mahasiswa.

Langkah berikutnya, untuk memberi contoh pengajar dapat melengkapi salah satu cabang utama dengan ide-ide pendukung yang termasuk dalam kategori itu. Pada cabang utama Wann? dapat dilengkapi dengan ranting "Juli" dan "nach der Prüfung". Cabang-cabang utama berikutnya dapat dilengkapi oleh pembelajar dibawah bimbingan pengajar. Mereka dapat melengkapinya dengan memberi warna atau ikon-ikon tertentu supaya menarik dan mudah diingat. Setelah Mind Map selesai disusun, pembelajar dapat diminta untuk menuliskan karangannya sesuai dengan peta pemikiran yang ada. Dengan demikian Mind Map berfungsi sebagai panduan bagi mahasiswa dalam menulis karangannya sehingga karangan yang ditulis diharapkan memiliki kesatuan makna yang utuh.

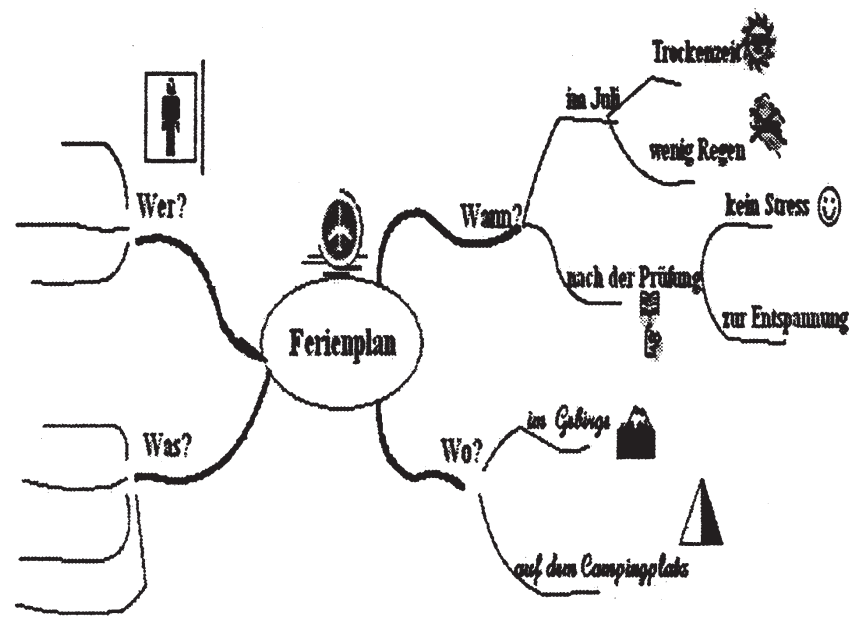

Gambar 2. Mind Map untuk tema "Ferienplan" 


\section{Mind Map dan Pengembangan Keterampilan Membaca Teks Berbahasa Jerman}

Keterampilan membaca dan mendengar merupakan keterampilan berbahasa yang bersifat reseptif. Kegiatan membaca dilakukan untuk memperoleh makna dari sebuah teks yang ditulis dalam Bahasa tertentu. Sedang kegiatan mendengar dapat dipahami sebagai kegiatan mengambil makna dari teks lisan yang diucapkan oleh seorang pembicara atau partner bicara. Dengan demikian pembaca dan pendengar memperoleh input dari luar berupa teks tulis atau teks lisan yang harus diuraikan (decoding) agar diperoleh pemahaman yang baik.

Pemahaman yang baik akan diperoleh jika pembaca mampu menggunakan teknik yang tepat berdasarkan tujuan yang ingin dicapai. Pada dasarnya kegiatan membaca dapat dibagi dalam tiga jenis (Bolton, 1995:22) yaitu: (1) Membaca secara global, (2) membaca secara detil dan (3) membaca secara selektif.

Membaca secara global dilakukan jika pembaca atau pendengar ingin memahami teks tulis atau lisan secara garis besarnya saja. Oleh karena itu saat membaca tidak perlu setiap kata harus diketahui maknanya. Hal ini dilakukan ketika seorang membaca novel atau sebuah roman. Sebaliknya, membaca secara detil dilakukan jika pembaca ingin memahami dengan tepat setiap bagian dari teks. Sebagai contoh adalah saat pembaca ingin memasak berdasarkan resep masak di sebuah majalah. Membaca secara selektif dilakukan jika pembaca ingin menemukan informasi tertentu yang dicari, ketika ia telah menemukan informasi tersebut ia akan menghentikan kegiatannya. Contoh, seorang yang ingin bepergian ke Jakarta dengan kereta api di pagi hari, saat membaca jadwal perjalanan KA ia akan membacanya secara selektif. Ketiga jenis membaca tadi sebenarnya dilakukan oleh manusia setiap hari. Oleh karena itu dalam pengajaran bahasa Jerman ketiganya juga dilatihkan, dengan harapan pembelajar akan dapat menerapkannya dalam konteks riil.

Terkait dengan pengembangan keterampilan membaca, Mind Map dapat digunakan sebagai alat bantu untuk mempermudah pembaca memperoleh pemahaman. Pada pengajaran keterampilan berbahasa 
yang bersifat reseptif ini, Mind Map lebih tepat digunakan sebagai alat bantu pada kegiatan membaca secara global. Mind Map dapat diberikan sebelum, dan sesudah kegiatan membaca dilakukan.

Jika Mind Map diberikan sebelum kegiatan membaca, maka ia akan berfungsi seperti Advance Organizer yang mempunyai tujuan membantu pembelajar mengurangi hambatan dalam memahami sesuatu (Scherling, 1992:94). Hambatan itu dapat disebabkan oleh faktor linguistik atau non-linguistik seperti latar belakang pengetahuan, pengetahuan budaya dan minat membaca. Dalam hal ini, Mind Map dapat merangsang pembelajar untuk mengaktifkan pengetahuan yang dimilikinya dan mengkaitkannya dengan informasi yang tergambarkan dalam Mind Map.

Prosedur yang dilakukan jika Mind Map difungsikan sebagai advance organizer adalah: (1) Pengajar menentukan tema dari teks bahasa Jerrnan yang akan diberikan pada mahasiswanya. Tema bacaan dapat ditentukan dari judul bacaan, yang kemudian dituangkan sebagai gagasan sentral. Agar lebih imajinatif gagasan sentral ini dapat dilengkapi dengan gambar atau ikon tertentu. (2) Dari gagasan sentral yang menggambarkan tema bacaan tersebut, pengajar menyusun cabang-cabang utama yang merupakan pendukung dari gagasan sentral tersebut dan dihubungkan dengan garis lengkung dengan warna tertentu. Isi dari cabang utama hendaknya dituangkan dalam satu kata kunci agar lebih mudah dipahami. Cabang utama ini dapat diperoleh dari masing-masing paragraf yang ada di dalam bacaan. (3) Selanjutnya dari tiap cabang utama tersebut disusun ide pendukung di level berikutnya yang merupakan anak cabang dari cabang utama. Demikian seterusnya. Mind Map yang tersusun tersebut merupakan gambaran secara global mengenai isi sebuah teks. (4) Kemudian, Mind Map tersebut disajikan pada pembelajar dan mereka diminta untuk mencoba menceritakan secara garis benar pemahaman mereka terhadap Mind Map itu.

Tahap pembacaan Mind Map yang dilakukan sebelum kegiatan membaca ini merupakan fase awal bagi pembelajar agar mereka memiliki prediksi atau hipotesis sementara mengenai isi teks. Hipotesis ini

DIKSI Vol.12, No.2, Juli 2005 
merupakan pemahaman awal yang dimiliki mahasiswa sebelum membaca teks. Prediksi ini dalam proses membaca berperan penting, karena akan menjadi semacam panduan bagi pembaca saat ia membaca teks. Ketika proses membaca dilakukan, pembaca harus melakukan verifikasi apakah prediksi yang ia susun sebelumnya benar atau salah. Jika hipotesis yang disusun salah, pembaca harus merevisi ulang prediksinya yang berarti juga merevisi pemahaman awal yang ia miliki, dan pada saat itulah sebenarnya pembaca sedang mengkonstruksi pemahamannya terhadap teks. Sedang bila prediksinya benar, maka itu akan memperkuat pemahaman awalnya hingga ia memiliki pemahaman utuh terhadap isi teks.

Mind Map yang diberikan sesudah proses membaca berlangsung merupakan alat untuk melatih pembelajar membuat semacam ringkasan dari isi teks yang dibaca. Pengajar mula-mula menyusun sebuah Mind Map yang belum lengkap, misal pengajar hanya menuliskan cabang-cabang utamanya saja. Anak cabang dan ranting-rantingnya harus dilengkapi oleh pembelajar berdasarkan isi yang ada dalam teks. Pada tahap awal pengajar dapat memilih teks pendek yang sederhana. Selanjutnya ketika pembelajar sudah dapat melengkapi Mind Map tersebut dengan baik, pengajar secara bertahap dapat memberikan teks yang lebih panjang dan lebih sulit.

Melalui cara ini pembelajar akan dilatih untuk mengelompokan informasi-informasi yang ada dalam teks berdasarkan tingkat kebermaknaannya, juga berlatih untuk melihat hubungan antar informasi, sekaligus menyusun informasi tersebut dalam bentuk bagan yang terstruktur. Menurut Jung (2003:121) salah satu teknik belajar yang perlu dilatih dalam keterampilan membaca adalah menyusun atau meringkas isi bacaan secara terstruktur.

Mind Map yang telah dilengkapi tadi selanjutnya dapat digunakan sebagai media untuk melatih kemampuan berbicara dan menulis, dengan cara pembelajar diminta memaparkan kembali pemahamannya mengenai isi teks secara lisan atau tertulis. Ini sekaligus merupakan cara untuk melatih pembelajar mereproduksi sebuah teks. 
Latihan membuat Mind Map dari sebuah teks tulis berbahasa Jerman semacam ini akan sangat bermanfaat bagi mahasiswa terutama saat mereka kelak dituntut untuk mampu memahami berbagai buku atau artikel yang ditulis dalam bahasa Jerman, seperti dalam mata kuliah Linguistik atau Literatur. Mahasiswa akan dilatih untuk membuat catatan yang efektif dalam bentuk Mind Map.

Berikut ini akan diberikan contoh penyusunan Mind Map yang dibuat berdasarkan teks berjudul Kein Geld für Irokesen. Teks ini terdapat dalam buku ajar bahasa Jerman Themen Neu 2 yang merupakan buku acuan utama dalam pengajaran bahasa Jerman di Program Studi Pendidikan Bahasa Jerman FBS UNY

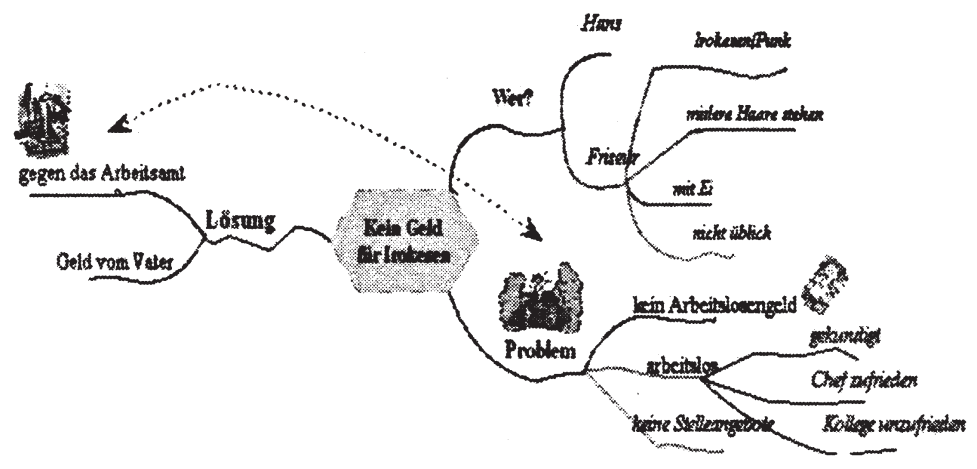

Gambar 3. Mind Map untuk teks "Kein Geld für Irokesen”

\section{E. Penutup}

Pengembangan keterampilan berbahasa baik yang bersifat reseptif atau produktif dapat dilakukan dengan berbagai cara. Salah satu alat yang dapat digunakan untuk itu adalah Mind Map. Mind Map merupakan cara untuk memetakan ide atau konsep dalam sebuah grafik sehingga ide-ide tersebut dapat dengan mudah diingat (remembering) ataupun dipanggil kembali (recalling) dari memori. Mind Map disusun dengan menggunakan prinsip kerja otak yaitu asosiasi dan imajinatif, sekaligus memaksimalkan fungsi belahan otak kanan dan kiri. 
Pemanfaatan Mind Map dalam pengembangan keterampilan menulis adalah untuk mengurangi salah satu kelemahan yang sering dijumpai pada pembelajar bahasa Jerman, yaitu ketidakmampuan menyusun karangan yang memiliki koherensi baik. Dalam hal ini Mind Map merupakan alat untuk mengorganisir ide-ide sehingga karangan memiliki kesatuan makna yang utuh. Selain itu Mind Map akan membantu agar pembelajar tidak melakukan lompatan alur berpikir saat menulis karangan dalam bahasa Jerman.

Pada keterampilan membaca, Mind Map dapat digunakan pada awal sebelum kegiatan membaca, dan selama atau sesudah kegiatan membaca. Jika Mind Map diterapkan sebelum kegiatan membaca dimulai, ia akan berfungsi sebagai pengatur awal (advance organizer) yang akan memberikan gambaran global mengenai isi teks, sekaligus membantu pembelajar untuk mengaktifkan latar belakang pengetahuan yang dimilikinya. Dengan cara seperti itu pembaca dapat menyusun hipotesis awal yang berfungsi sebagai pemandu saat membaca. Sebaliknya jika Mind Map digunakan selama atau sesudah kegiatan membaca, maka Mind Map akan berfungsi sebagai wahana untuk mengorganisir ide-ide pokok yang ada dalam teks. Dengan cara seperti itu pembaca juga akan berlatih untuk membuat catatan yang efektif. Keterampilan menyusun sebuah Mind Map dari sebuah teks tulis dalam bahasa Jerman akan sangat bermanfaat ketika mahasiswa membaca karya sastra Jerman atau buku teks bahasa Jerman.

\section{DAFTAR PUSTAKA}

Aprea. C., \& Mastroserio. M. Lerntechnik: Mind-Mapping. Diakses dari: www.Franz-Boehm-Schule.de/mind-mapping.htm

Bolton, Sybille. 1995. Probleme der Leistungsmessung: Lernfortschritttest in der Grundstufe. München: Goethe Institut.

Buzan, Tony. 2004. Mind Map untuk meningkatkan Kreativitas. Jakarta: Penerbit Gramedia.

Mind Map dalam Pengajaran Keterampilan Menulis (Iman Santoso) 
Dalrymple, Jennifer Blakely. Teaching and Learning Law with Graphic Organizers. Diakses dari www.loyno.edu/ dciolino/classes/ graphicorganizers.htm

Heuer, Wiebke. 2001. Mind Maps im Fremdsprachenunterricht. Muenchen: Max Hueber Verlag. Diakses dari www.hueber.de/ downloads/lehrer/daf/mind-maps.pdf

Jung, Lothar. 2003. 99 Stichwörter zum Unterrich Deutsch als Fremdsprache. Diakses dari www.hueber.de/downloads/lehrer/ fs/lernte.pdf

Lee, Chien-Ching. 2004. Seeing is Understanding: Improving coherence in Students' Writing. Dalam The Internet TESL Journal, Vol.X. No. 7, July 2004. Diakses dari http://iteslj.org/techniquea/LeeWrting/

Malia, Lia. 2004. Peningkatan Keterlibatan Mahasiswa dalam Keterampilan Menulis Bahasa Jerman melalui Asosiogram. Jurnal Litera: Jurnal Penelitian Bahasa, Sastra dan Pengajarannya. Vol. 3, No. 1 Januari 2004. Yogyakarta: FBS - UNY

Scherling, Theo. \& Schuckal, Hans-Friedrich. 1992. Mit Bildern Lerrnen, Handbuch für den Fremdsprachenunterricht. München: Langenscheidt.

Suparno, Paul. 2004. Teori Intelegensi Ganda dan Aplikasinya di Sekolah: Cara Menerapkan Teori Multiple Intelengences Howard Gardner. Yogyakarta: Penerbit Kanisius.

, Definition of Mind Map. Diakses dari: http://www.mind-map. com/EN/mindmaps/definition.html

, The Mind Map Galery. Diakses dari: http://www.mind-map. com/EN/mindmaps/gallery.html

DIKSI Vol.12, No.2, Juli 2005 